\title{
THE CONTENT OF POLYCHLORINATED BIPHENYLS AND ORGANOCHLORINE PESTICIDES IN TISSUES OF DATE MUSSEL (Lithophaga lithophaga, L., 1758) FROM THE SARAJEVO FISH MARKET
}

\author{
Elma E. Omeragić ${ }^{*}$, Aleksandra A. Marjanović, Jasmina J. Đeđibegović, Amila A. Dobrača, \\ Miroslav M. Šober \\ University of Sarajevo, Faculty of Pharmacy, 71000 Sarajevo, Zmaja od Bosne, 8, Bosnia and \\ Herzegovina
}

\author{
Corresponding author: \\ Phone: +387 33586178 \\ Fax: +38733586178 \\ E-mail: elma.omeragic1465@gmail.com
}

\begin{abstract}
Persistent organic pollutants (POPs) are chemicals of global concern due to their potential for long-range transport, persistence in environment, ability to biomagnify and bioaccumulate in ecosystems, as well as their significant negative effects on human health and the environment.

In this study, seven targeted polychlorinated byphenils (PCBs, IUPAC Nos. 28, 52, 101, 118, 138 , 153, and 180) and the organochlorine pesticides (OCPs) aldrin, dieldrin, endrin, cis-chlordane, transchlordane and oxy-chlordane were quantified in European date mussel (Lithophaga lithophaga L., 1758.) collected from the Sarajevo fish market (Bosnia and Herzegovina). This slow-growing species is widespread along the whole Mediterranean rocky coastline. In Bosnia and Herzegovina $(\mathrm{BiH})$, this species has not been protected by law and the date mussel harvested in the area of the Neum bay (Adriatic sea) could be found in free sale on $\mathrm{BiH}$ market.

Applied gas chromatography and tissue extraction methods were validated in the NIVA laboratory. Our samples $(n=61)$ were $4.5-8.4 \mathrm{~cm}$ in length. Total OCPs in the analyzed samples were low (ranging from non-detectable to $0.419 \mu \mathrm{g} \mathrm{kg}^{-1}$ w.w.), while $\Sigma 7 P C B s$ was ranging from 20.26 to $135.37 \mu \mathrm{g} \mathrm{kg}^{-1}$ w.W.. PCBs 101, 118, 138 and 153 were dominant congeners in all samples.
\end{abstract}

Key words: shellfish, persistent organic pollutants, polychlorinated byphenils, organochlorine pesticides, biomarker of exposure

\section{INTRODUCTION}

Contamination of the ecosystems of the coastal area and toxic substances present in aquatic organisms pose risks to human population and the environment, placing itself as one of the global problems of environmental pollution.

Particularly interesting is a group of semivolatile organic compounds, first of all polychlorinated biphenyls (PCBs) and organochlorine pesticides (OCPs). Polychlorinated biphenyls and organochlorine pes- ticides are ubiquitous contaminants with high hydrophobicity, thermal and photo stability, significant toxicity, low reaction potential and the high degree of resistance to degradation processes in environmental media (Herceg Romanić, 2002). Because of their strong tendency for bioaccumulation and biomagnification in different life forms, this group of substances is especially dangerous for organisms at a higher positon in food chain, mainly predatory animals and humans. Aquatic environ- 
ments offer the best conditions for bioaccumulation of these compounds. There is a myriad of organisms that filter and leak through their own body an enormous amount of water, thereby extract toxicants that have property of accumulation. Aquatic organisms accumulate substances in concentrations thousands of times greater than found in the waters. Once a substance enters the living organism, it can be moved through the food chain of organisms, victims, (herbivores) to consumer organisms (predators) that feed on them. For high lipophilic compounds, this movement can be accomplished by concentrating the toxicant in the tissues of each successive body that makes links in a food chain (Jones and Voogt, 1999).

Date mussel ( $L$. lithophaga) is a mollusk of the class of the Bivalvia, dwelling in the underwater rocks and stones which in pierces by secreting hydrochloric acid. Given that it lives in the rocks, the growth is limited, so it could take between 18 and 36 years to reach a commercial size of 5 $\mathrm{cm}$. They can reach an age $>54$ years (Galen-Mitsoudi and Sinis, 1995; Devescovi and Iveša, 2004; Guidetti and Boero, 2004).

They are distributed from the Eastern Atlantic, across the Mediterranean to the Red Sea. Due to the fact that they are static organisms with a specific lifestyle and slow rate growth, which feed by filtering particles from the water they represent an aquatic organism with the high potential of bioaccumulation of toxicants. It is one of the most prized shellfish to eat, but due to their specific lifestyle and slow growth they are not suitable for cultivation (Bratoš and Glamuzina, 2004).

As for the extraction of this shellfish, it is necessary to break rocks, and therefore by its fishing large coastline rocky areas are destroyed which results in destruction of habitats and biological diversity. In most countries, the law strictly prohibits catching, holding, killing, purchasing, sale, acquisition or alienation otherwise, export or import of date mussel, and damaging and destroying of their habitats. In Bosnia and Herzegovina $(\mathrm{BiH})$, this species is not yet protected by law and in $\mathrm{BiH}$ market the date mussel harvested in the area of the Neum bay could be found in free sale.

In this experiment, the presence and the content of the selected groups of persistent organic pollutants (organochlorine insecticides, total PCBs and individual PCBs congeners) in samples of date mussel (L. lithophaga) collected from the Sarajevo seafood market, were analyzed. The obtained results could serve to form the baseline for the assessment of risk to public health.

Based on performed preliminary tests it was necessary:

- To select the commercial sources from which the samples would be obtained;

- To carry out the extraction and purification of the selected group of persistent organic pollutants from samples of shellfish;

- To conduct an analysis of the prepared extracts according to established protocols using the method of gas chromatography with electron capture detector (GC-ECD);

- To compare the obtained results of the contents of the selected group of persistent organic pollutants with the limits of their maximum levels in foods, according to the appropriate regulations in Bosnia and Herzegovina and the European Union.

\section{MATERIALS AND METHODS}

\section{Chemicals and reagents}

Cyclohexane, 2-propanol (all HPLC grade) and tetrabutylammonium sulphate (p.a.) were from Sigma-Aldrich (Seelze, Germany). Sodium chloride (p.a.) was from Kemika (Zagreb, Croatia). Sulphuric acid (98\%, extra pure) was from Merck (Darmstadt, Germany). PCB standard (PCB204, PCB53 and PCB30) was purchased from $\mathrm{Dr}$ Ehrenstorfer $\mathrm{GmbH}$ (Augsburg, Germany). Nitrogen 5.0 (Messer, Sarajevo, BiH) was used for evaporation of extracts. The ultrapure water was used for preparation of reagents and samples treatment. Reference material for fish and shellfish tissue was prepared in the Norwegian Institute for Water Research NIVA, Oslo. 


\section{Sampling of date mussel}

Samples of date mussel, Lithophaga lithophaga L. 1758, were obtained from the commercial sources. As commercial sources, local fish market in the city of Sarajevo was selected.This fish market was the only one where date mussels could be procured in Sarajevo. Samples of date mussels analyzed for the presence of selected groups of persistent organic pollutants, after acquisition at the fish market (in August 2014), were transported to the laboratory where the clams of shell were opened, body taken out and prepared for further analysis. Before opening, each shellfish was weighed and measured/recorded, alongside with the mass and length. The weight was determined by using an electronic scale $(0.01 \mathrm{~g})$ and the length by using a graph paper. All glassware and equipment used in the processing of tissue samples were carefully selected and the action was taken to prevent subsequent contamination.

\section{Tissue extracts preparation}

Since individual samples were originating from the same habitat (area of the Neum bay) it has been assumed that the individuals of the same age, because of the same environmental conditions for growth, have reached the same length growth (Galinou-Mitsoudi and Sinis, 1995). Out of individual samples the aggregate samples were prepared and further analyzed as a single sample. Aggregate samples included the samples of Data mussel with the same shells length. A total of 16 aggregate samples and 9 samples representing individual shells were analyzed. The samples were homogenized using a mortar and pestle. To the precisely measured aliquots (about $2 \mathrm{~g}$ ) of homogenized tissue samples, $40 \mathrm{ml}$ of a mixed solvent cyclohexane:2-propanol $(1: 1 \mathrm{v} / \mathrm{v})$ was added.

An internal standard $(50 \mu \mathrm{l})$ was added to the blank (solvents) and to the reference material. Samples were further transferred to an ultrasonic bath (Clifton, Canonsburg, PA, USA) for $15 \mathrm{~min}$, then on the shaker Promax 1020 (Heidolph, Schwabach, Germany) for one hour, after which they were centrifuged (IEC CL-10
Centrifuge, Thermo Fisher Scientific Inc., USA) for 5 minutes at $1488 \times \mathrm{xg}$. The solution was decanted into new bottles, and extraction was repeated with $30 \mathrm{ml}$ of a mixed solvent in the same manner. To the combined extract of the sample $15 \mathrm{ml}$ of sodium-chloride solution $(0.5 \%)$ was added and after the content was shaken it was centrifuged for 5 minutes at $1488 \times$ g. The organic layer was then transferred into the clean test tubes and evaporated to dryness $\left(36{ }^{\circ} \mathrm{C}\right)$ in a stream of nitrogen. The mass residue after evaporation of the solvent gives the amount of fat in the sample. To each of the measured aliquot of fat $1 \mathrm{ml}$ of cyclohexane and $50 \mu \mathrm{L}$ of the internal standard were added and all was mixed on a vortex (Scientific Industries, NY, USA). Subsequently, the content was transferred to the clean test tubes, washed up with a small volume of cyclohexane to a total volume of $2 \mathrm{ml}$ and cleaned twice with concentrated sulphuric acid $(2 \mathrm{~mL})$. The sulfur residue was removed by adding tetrabutylammonium sulfate (TBA). Cyclohexane layer was transferred to the new tubes and re-treated with the addition of $0.5-1.0 \mathrm{ml}$ of sulfuric acid. After mixing and centrifugation acid layer was removed, and the cyclohexane extract was evaporated under a stream of nitrogen to a volume of $150-200 \mu \mathrm{L}$ and transferred to vials for $\mathrm{GC}$.

\section{Determination of OCPs and PCBs}

Qualitative and quantitative analyses of the selected compounds were carried out by using gas chromatography system (Agilent Tecnologies series 7890A GC System USA), equipped with a split-splitless injector $\left(250{ }^{\circ} \mathrm{C}\right)$ and electron capture detector $\left(300{ }^{\circ} \mathrm{C}\right)$. Nitrogen $\left(1 \mathrm{ml} \mathrm{min}^{-1}\right)$ was used as a carrier gas. The capillary column HP-5 $60 \mathrm{~m} \times 0.25 \mathrm{~mm}$ with film thickness $0.25 \mu \mathrm{m}$ (Agilent Tecnologies) was used. The temperature program was: initial temperature $90{ }^{\circ} \mathrm{C}(2 \mathrm{~min})$, to $180{ }^{\circ} \mathrm{C}$ at a rate of $20^{\circ} \mathrm{C} \mathrm{min}{ }^{-1}$, to $270{ }^{\circ} \mathrm{C}$ at a rate of $2{ }^{\circ} \mathrm{C} \mathrm{min}{ }^{-1}$, to $310^{\circ} \mathrm{C}$ at a rate of $20^{\circ} \mathrm{C}$ $\mathrm{min}^{-1}$, and holding at this temperature for 5 $\min$.

Analized compounds were identified by comparing their retention times with standard mixtures of the investigated com- 
pounds. The quantification of the individual components was performed based on the relative response of each component relative to the internal standard. As an internal standard PCB204 was used for components PCB101, PCB118, PCB138, PCB 153 and PCB180; PCB53 was used for PCB28 and PCB52; while PCB30 was used for quantification of organochlorine insecticide.

Each batch of samples was analyzed together with one aliquot of reference material and blank. The limit of detection (LoD) and limit of quantification (LoQ) were calculated (using MS Excel) for each analyzed compounds from the standard deviation and slope of the calibration curve which was evaluated on the basis of data obtained from a series of 6 calibrations standard (Miller and Miller, 2000).

\section{RESULTS AND DISCUSSION}

\section{Characteristics of the analyzed samples}

The length of the shell, total mass and mass of tissue were determined for each specimen. Length of individuals was in the range $4.5-8.4 \mathrm{~cm}$. Fat content ranged from 0.2 to $3.05 \%$ (Table 1 ).

\section{The content of OCPs}

Concentrations of OCPs were presented for individual organochlorine compounds and as the sum of total OCPs present in individual samples. Results are shown in the Table 2.

Table 1.

Characteristics of the analysed samples

\begin{tabular}{cccc}
$\begin{array}{c}\text { Sample } \\
\text { ID }\end{array}$ & ID of individuals in the aggregated sample & $\begin{array}{c}\text { Shell length } \\
(\mathrm{cm})\end{array}$ & $\begin{array}{c}\text { Fat content } \\
(\% \text { w.w. })\end{array}$ \\
\hline NP1 & 1 & 4.5 & 0.53 \\
NP2 & 2 & 4.8 & 0.66 \\
NP3 & 3 & 4.9 & 0.25 \\
NP4 & 4 and 5 & 5 & 1.82 \\
NP5 & 6 and 7 & 5.2 & 0.20 \\
NP6 & 8 & 5.4 & 0.43 \\
NP7 & $9,10,11,12,13,14$ and 15 & 5.7 & 0.88 \\
NP8 & 21 and 22 & 5.8 & 0.51 \\
NP9 & $16,17,18,19$ and 20 & 5.6 & 0.66 \\
NP10 & 23 and 24 & 5.9 & 1.06 \\
NP11 & $25,26,27,28,29,30,31,32$ and 33 & 6.0 & 0.75 \\
NP12 & 34 and 35 & 6.1 & 1.55 \\
NP13 & 36 & 6.2 & 2.03 \\
NP14 & 37.38 and 39 & 6.3 & 2.03 \\
NP15 & 40 & 6.4 & 2.59 \\
NP16 & 41.42 .43 and 44 & 6.5 & 2.64 \\
NP17 & 45 & 6.6 & 2.25 \\
NP18 & 46.47 .48 and 49 & 6.7 & 1.20 \\
NP19 & 50 and 51 & 7 & 1.38 \\
NP20 & 53 and 54 & 6.8 & 1.90 \\
NP21 & 55 and 56 & 7.1 & 1.78 \\
NP22 & 52 and 57 & 7.4 & 3.05 \\
NP23 & 60 & 8.3 & 1.21 \\
NP24 & 61 & 8.4 & 2.85 \\
NP25 & 58 and 59 & 7.5 & 2.12 \\
\hline & & &
\end{tabular}


When the amount of analyzed compounds was lower than the limit of detection, compounds were reported as not detected (ND). LoD was $0.02,0.70,0.07,0.16,0.01$ and $0.03 \mu \mathrm{g} \mathrm{kg}^{-1}$ for aldrin, dieldrin, endrin, cis-, oxy- and trans-chlordane, respecttively. The recovery factors were 100,101 , 100, 99, 100 and $98 \%$ for aldrin, dieldrin, endrin, cis-, oxy- and trans-chlordane, respectively.

The presence of $o x y$-chlordane was detected in 24 out of 25 samples, and transchlordane in all analyzed samples. Since the content of any component analyzed was not calculated for quantities less than the method quantification limit, the content of oxy-chlordane was expressed only in 5 (NP1-NP4 and NP17) samples out of 25 in which it was detected, and trans-chlordane in 10 (NP1-NP5, NP9, NP13, NP18, NP19 and NP24) samples out of 25, where its presence was detected. The content of oxy-chlordane ranged from 0.096 to 0.101 $\mu \mathrm{g} \mathrm{kg}^{-1} \mathrm{w} . \mathrm{w}$. and for trans-chlordane from 0.041 to $0.100 \mu \mathrm{g} \mathrm{kg}^{-1} \mathrm{w} . \mathrm{w}$. So, in all analyzed samples, the presence of chlordane (its trans-isomer or its metabolite oxy-chlordane) was detected.

In all of the analyzed samples, aldrin was present in quantities above the detection limit, but its content was calculated for the two samples (NP13, and NP18) because it was above the method quantification limit for aldrin and it ranged from 0.071 to 0.105 $\mu \mathrm{g} \mathrm{kg}{ }^{-1}$ w.w.

The presence of dieldrin was detected in 13 samples, whereas only in three samples (NP2, NP9 and NP18) it was possible to quantify its content $(0.192,0.370$ and $0.365 \mu \mathrm{g} \mathrm{kg}^{-1}$ w.w., respectively).

Endrin was present in all samples in concentrations greater than the method detection limit. However, only in two samples, (NP9 and NP13), the content was greater than the method quantification limit (0.225 and $0.266 \mu \mathrm{g} \mathrm{kg}{ }^{-1}$ w.w., respectively).

It was possible to calculate the content of total analyzed organochlorine pesticides only in 11 samples (NP1-NP5, NP9, NP12, NP13, NP17-NP19 and NP24), ranging from 0.042 to $0.646 \mu \mathrm{g} \mathrm{kg}^{-1} \mathrm{w} . \mathrm{W}$.
The relative exposure time of analyzed sample to the aldrin and trans-chlordane could be estimated on the basis of the ratio of the metabolite (dieldrin and oxychlordane) compared to the parent compound (Di Muccio et al., 2002).

The ratio between the amount of dieldrin and aldrin could be calculated only for sample 18 and it was greater than 1 (dieldrine/aldrine=5.14). On the other hand, the ratio between the amount of oxy-clordane and trans-chlordane was calculated for samples NP1-NP4 (because only in these samples the content of both trans- and oxy- chlordane was determined). In these samples this ratio was $>1(1.38,1.74,2.46$ and 2.06, respectively). Higher amount of the aldrin and trans-chlordane metabolites compared to the parent substances may refer to the historical intake of aldrin and trans-chlordane, or the exposure of the analyzed organisms to dieldrin and oxychlordane, or dieldrin and oxy-chlordane being created as a result of degradation of parent compounds by the environmental conditions and the absence of metabolic systems for the breakdown and transformation of oxy-chlordane and dieldrin in date mussel.

Tables 3, 4 and 5 provide a percentage of the total number of analyzed samples that could be consumed by the estimated number of meals during the month, according to the guidelines provided by the EPA due to chronic cancer and noncancerous effects (EPA, 2000) of chlordane, dieldrin and endrin in relation to the content in the tissue of date mussel.

In all 25 analyzed samples, the pesticide content, calculated on a serving size base i.e. $0.227 \mathrm{~kg}$, was far below the limit permitted for the monthly consumption of more than 16 such meals.

The limit in organochlorine pesticide content for shellfish has not been set in the European Union. In Bosnia and Herzegovina, the content of aldrin, dieldrin, endrin and chlordane in food is regulated by the Regulation on the quantities of pesticides and other toxic substances, hormones, antibiotics and mycotoxins (Pravilnik, 1983). 
However, the Regulation does not explicitly state the allowed aldrin and dieldrin contents in shellfish, but provides the limits for these contaminants in meat, fat and meat products.

According to this Regulation, the permitted content for aldrin and dieldrin in meat, fat and meat products, is $0.1 \mathrm{mg} \mathrm{kg}^{-1}$. The limits for endrin and chlordane are given re- gardless on the type of food and they are $0.001 \mathrm{mg} \mathrm{kg}^{-1}$ for endrin and $0.05 \mathrm{mg} \mathrm{kg}^{-1}$ for chlordane.

The content of the analized organochlorine pesticides, determined by our study in date mussel is far below these limits, and, on the basis of these results, date mussel from the Neum bay could be evaluated as safe for consumption.

Table 2.

Concentration of individual and total OCPs ( $\mu \mathrm{g} / \mathrm{kg}$ w.w.) in date mussel tissue samples

\begin{tabular}{|c|c|c|c|c|c|c|c|}
\hline $\begin{array}{c}\text { Sample } \\
\text { ID }\end{array}$ & ALDRIN & DIELDRIN & ENDRIN & $\begin{array}{c}\text { CIS- } \\
\text { CHLORDANE }\end{array}$ & $\begin{array}{c}\text { OXY- } \\
\text { CHLORDANE }\end{array}$ & $\begin{array}{c}\text { TRANS- } \\
\text { CHLORDANE }\end{array}$ & $\Sigma O C P$ \\
\hline NP1 & $<0.070^{\mathrm{a}}$ & $<0.240$ & $<0.230$ & $\mathrm{ND}^{\mathrm{b}}$ & 0.099 & 0.072 & 0.171 \\
\hline NP2 & $<0.070$ & 0.192 & $<0.230$ & ND & 0.096 & 0.055 & 0.343 \\
\hline NP3 & $<0.070$ & ND & $<0.230$ & ND & 0.101 & 0.041 & 0.142 \\
\hline NP4 & $<0.070$ & $<0.119$ & $<0.230$ & ND & 0.099 & 0.048 & 0.147 \\
\hline NP5 & $<0.070$ & ND & $<0.230$ & ND & $<0.095$ & 0.100 & 0.100 \\
\hline NP6 & $<0.070$ & $<0.240$ & $<0.230$ & ND & $<0.095$ & $<0.040$ & ND \\
\hline NP7 & $<0.070$ & $<0.240$ & $<0.230$ & ND & $<0.095$ & $<0.040$ & ND \\
\hline NP8 & $<0.070$ & $<0.240$ & $<0.230$ & ND & $<0.095$ & $<0.040$ & ND \\
\hline NP9 & $<0.070$ & 0.370 & 0.225 & ND & $<0.095$ & 0.051 & 0.646 \\
\hline NP10 & $<0.070$ & ND & $<0.230$ & ND & $<0.095$ & $<0.040$ & ND \\
\hline NP11 & $<0.070$ & $<0.240$ & $<0.230$ & ND & $<0.095$ & $<0.040$ & ND \\
\hline NP12 & $<0.070$ & ND & $<0.230$ & ND & $<0.095$ & $<0.040$ & ND \\
\hline NP13 & 0.105 & $<0.240$ & 0.266 & ND & $<0.095$ & 0.051 & 0.422 \\
\hline NP14 & $<0.070$ & ND & $<0.230$ & ND & $<0.095$ & $<0.040$ & ND \\
\hline NP15 & $<0.070$ & $<0.240$ & $<0.230$ & ND & ND & $<0.040$ & ND \\
\hline NP16 & $<0.070$ & ND & $<0.230$ & ND & $<0.095$ & $<0.040$ & ND \\
\hline NP17 & $<0.070$ & ND & $<0.230$ & ND & 0.098 & $<0.040$ & 0.098 \\
\hline NP18 & 0.071 & 0.365 & $<0.230$ & ND & $<0.095$ & 0.054 & 0.490 \\
\hline NP19 & $<0.070$ & $<0.240$ & $<0.230$ & ND & $<0.095$ & 0.052 & 0.052 \\
\hline NP20 & $<0.070$ & ND & $<0.230$ & ND & $<0.095$ & $<0.040$ & ND \\
\hline NP21 & $<0.070$ & ND & $<0.230$ & ND & $<0.095$ & $<0.040$ & ND \\
\hline NP22 & $<0.070$ & ND & $<0.230$ & ND & $<0.095$ & $<0.040$ & ND \\
\hline NP23 & $<0.070$ & ND & $<0.230$ & ND & $<0.095$ & $<0.040$ & ND \\
\hline NP24 & $<0.070$ & $<0.240$ & $<0.230$ & ND & $<0.095$ & 0.0420 & 0.042 \\
\hline NP25 & $<0.070$ & ND & $<0.230$ & ND & $<0.095$ & $<0.040$ & ND \\
\hline
\end{tabular}

$a^{a}<"$ values indicate concentrations below the quantification method limit; ${ }^{b} \mathrm{ND}-$ not detected

Table 3.

Monthly shellfish consumption limits for carcinogenic and noncarcinogenic health endpoints for chlordane in relation to the concentration found in date mussel collected from the Neum bay

\begin{tabular}{ccccc}
\hline $\begin{array}{c}\text { Shelfish } \\
\text { meals/month }^{\mathbf{a}}\end{array}$ & MAC $^{\mathbf{b}}$ & $\mathbf{C}>\mathbf{M A C}^{\mathbf{b}}$ & MAC $^{\mathbf{c}}$ & \multicolumn{1}{c}{$\mathbf{C ~ M A C}^{\mathbf{c}}$} \\
\cline { 2 - 5 }$>16$ & $\left(\mu \mathrm{g} \mathrm{g}^{-1}\right.$ W.w. & $(\%)$ & $\left(\mu \mathrm{g} \mathrm{g}^{-1}\right.$ W.w. $)$ & $(\%)$ \\
16 & $0-0.015$ & 100 & $0-0.0084$ & 0 \\
12 & $>0.015-0.29$ & 0 & $>0.0084-0.017$ & 0 \\
8 & $>0.29-0.39$ & 0 & $>0.017-0.022$ & 0 \\
4 & $>0.39-0.59$ & 0 & $>0.022-0.034$ & 0 \\
3 & $>0.59-1.2$ & 0 & $>0.034-0.067$ & 0 \\
2 & $>1.2-1.6$ & 0 & $>0.067-0.089$ & 0 \\
1 & $>1.6-2.3$ & 0 & $>0.089-0.13$ & 0 \\
\hline
\end{tabular}

${ }^{a}$ The assumed serving size is $0.227 \mathrm{~kg}$ of shellfish tissue

$M A C^{b}$ - maximum allowable concentrations due to chronic non-cancerous effects

$M A C^{c}$ - maximum allowable concentrations due to chronic cancerous effects 


\section{Table 4.}

Monthly shellfish consumption limits for carcinogenic and non-carcinogenic health endpoints for dieldrine in relation to the concentration found in date mussel collected from the Neum bay

\begin{tabular}{|c|c|c|c|c|}
\hline $\begin{array}{c}\text { Shelfish } \\
\text { meals/month }\end{array}$ & $\begin{array}{c}\text { MAC }^{\mathbf{b}} \\
\left(\mu \mathrm{g} \mathrm{g}^{-1} \text { w.w. }\right)\end{array}$ & $\mathbf{c}>\mathrm{MAC}^{\mathrm{b}}(\%)$ & $\begin{array}{c}\text { MAC }^{\mathbf{C}} \\
\left(\mu \mathrm{g} \mathrm{g}^{-1} \text { W.w. }\right)\end{array}$ & $\begin{array}{c}\mathbf{C}>\mathrm{MAC}^{\mathrm{C}} \\
(\%)\end{array}$ \\
\hline$>16$ & $0-0.015$ & 100 & $0-0.00018$ & 100 \\
\hline 16 & $>0.015-0.029$ & 0 & $>0.00018-0.00037$ & 0 \\
\hline 12 & $>0.029-0.039$ & 0 & $>0.00037-0.00073$ & 0 \\
\hline 8 & $>0.039-0.059$ & 0 & $>0.00073-0.0015$ & 0 \\
\hline 4 & $>0.059-0.12$ & 0 & $>0.0015-0.067$ & 0 \\
\hline 3 & $>0.12-0.16$ & 0 & $>0.067-0.002$ & 0 \\
\hline 2 & $>1.6-2.3$ & 0 & $>0.002-0.0029$ & 0 \\
\hline 1 & $>2.3-4.7$ & 0 & $>0.0029-0.0059$ & 0 \\
\hline
\end{tabular}

${ }^{\bar{a}}$ The assumed serving size is $0.227 \mathrm{~kg}$ of shellfish tissue

$M A C^{b}$ - maximum allowable concentrations due to chronic non-cancerous effects

$M A C^{c}$ - maximum allowable concentrations due to chronic cancerous effects

Table 5.

Monthly shellfish consumption limits for carcinogenic health endpoints for endrin in relation to the concentration found in date mussel collected from the Neum bay

\begin{tabular}{ccc}
\hline \multirow{2}{*}{ Shelfish meals/month } & MAC & C $>$ MAC \\
\cline { 2 - 3 } & $\left(\mu \mathrm{g} \mathrm{g}^{-1}\right.$ w.w. $)$ & $(\%)$ \\
\hline 16 & $0-0.088$ & 100 \\
16 & $>0.088-0.18$ & 0 \\
12 & $>0.18-0.23$ & 0 \\
8 & $>0.23-0.35$ & 0 \\
4 & $>0.35-0.7$ & 0 \\
3 & $>0.7-0.94$ & 0 \\
2 & $>0.94-1.4$ & 0 \\
1 & $>1.4-2.8$ & 0 \\
\hline
\end{tabular}

${ }^{a}$ The assumed serving size is $0.227 \mathrm{~kg}$ of shellfish tissue

MAC- maximum allowable concentrations due to chronic cancerous effects

According to the American Food and Drug Administration (FDA), limits for aldrin, dieldrin and chlordane in the edible parts of molluscs are $0.3 \mathrm{mg} \mathrm{kg}^{-1}$ (FDA, 2005). The content of these OCPs in our samples is far below the mentioned limit and therefore, according to the FDA issued regulations, date mussel from the Neum bay could be evaluated as safe for consumption.

\section{The content of PCBs}

Table 6 gives an overview of the concentration of individual congeners and total PCBs expressed in $\mu \mathrm{g} \mathrm{kg}^{-1}$ of wet weight. When the amount of PCB was lower than the limit of detection (LoD was $0.21,0.28$, $0.13,0.22,0.23,0.19$ and 0.09 for PCB28, PCB52, PCB101, PCB118, PCB153, PCB138 and PCB180, respectively) compounds were reported as not detected (ND). The recovery factors were 100, 102, 99, 99, 100, 103 and 99\% for PCB28, PCB52, PCB101, PCB118, PCB153, PCB138 and PCB180, respectively. Our study has shown that the content of the total seven PCBs in samples of date mussel soft tissue, ranged between 17.19 and $135.37 \mu \mathrm{g} \mathrm{kg}^{-1} \mathrm{w} . \mathrm{w}$.

Concentrations of individual congeners ranged from undetectable to the value of $59.72 \mu \mathrm{g} \mathrm{kg}^{-1}$ w.w. (PCB101 sample NP5). 
Table 6.

Concentration of indicator PCB congeners and total PCBs ( $\mu \mathrm{gg}^{-1}$ w.w.) in date mussel tissue samples

\begin{tabular}{|c|c|c|c|c|c|c|c|c|c|}
\hline \multirow{2}{*}{ Sample ID } & \multicolumn{9}{|c|}{ Concentration ( $\mu \mathrm{g} \mathrm{kg}^{-1}$ w.w.) } \\
\hline & PCB28 & PCB52 & PCB101 & PCB118 & PCB153 & PCB138 & PCB180 & $\Sigma 6 \mathrm{PCB}$ & 乏7PCB \\
\hline NP1 & 2.11 & $N^{b}$ & 2.87 & 2.43 & 26.09 & 3.22 & 1.16 & 35.45 & 37.88 \\
\hline NP2 & 2.18 & ND & 4.16 & 2.03 & 22.76 & 3.66 & 2.39 & 35.15 & 37.18 \\
\hline NP3 & 2.15 & ND & 3.52 & 2.23 & 24.42 & 3.44 & 1.78 & 35.31 & 37.54 \\
\hline NP4 & 2.21 & ND & 4.83 & 2.25 & 12.39 & 2.13 & 0.52 & 22.12 & 24.37 \\
\hline NP5 & 2.23 & ND & 59.72 & 25.93 & 34.34 & 11.99 & 1.16 & 109.44 & 135.37 \\
\hline NP6 & 2.05 & ND & 4.54 & 2.40 & 14.46 & 1.64 & 0.35 & 23.04 & 25.44 \\
\hline NP7 & 1.95 & ND & 8.73 & 6.27 & 17.79 & 5.32 & 1.91 & 35.70 & 41.97 \\
\hline NP8 & 1.87 & ND & 5.16 & 2.70 & 12.06 & 3.35 & 0.76 & 23.20 & 25.90 \\
\hline NP9 & 1.73 & ND & 15.71 & 7.51 & 16.60 & 5.72 & 1.89 & 41.65 & 49.16 \\
\hline NP10 & 1.78 & ND & 3.46 & 1.63 & 8.79 & 1.26 & 0.27 & 15.56 & 17.19 \\
\hline NP11 & 1.78 & ND & 10.33 & 4.96 & 11.67 & 3.82 & 1.14 & 28.74 & 33.70 \\
\hline NP12 & 1.45 & ND & 2.78 & 1.73 & 10.65 & 2.20 & 0.70 & 17.78 & 19.51 \\
\hline NP13 & 2.23 & ND & 2.72 & 1.69 & 13.12 & 2.04 & 0.53 & 20.64 & 22.33 \\
\hline NP14 & 5.43 & 13.58 & $<0.43^{\mathrm{a}}$ & ND & $<0.63$ & ND & ND & 19.01 & 19.01 \\
\hline NP15 & 1.75 & ND & 3.65 & 2.53 & 13.61 & 3.15 & 1.34 & 23.50 & 26.03 \\
\hline NP16 & 2.66 & 5.48 & 1.80 & 1.16 & 6.91 & 1.68 & 0.57 & 19.10 & 20.26 \\
\hline NP17 & 5.58 & 18.39 & 2.15 & 1.26 & 8.61 & 1.08 & 0.39 & 36.20 & 37.46 \\
\hline NP18 & 2.13 & ND & 5.86 & 2.90 & 23.87 & 3.26 & 1.66 & 36.95 & 39.85 \\
\hline NP19 & 1.90 & $<0.94$ & 26.39 & 10.40 & 19.35 & 6.18 & 1.37 & 55.19 & 65.59 \\
\hline NP20 & 1.83 & ND & 14.09 & 6.01 & 21.20 & 4.76 & 1.77 & 43.65 & 49.66 \\
\hline NP21 & 5.01 & 28.97 & 0.63 & $<0.73$ & $<0.63$ & ND & $<0.30$ & 34.61 & 34.61 \\
\hline NP22 & 10.48 & 11.98 & 3.18 & $<0.73$ & 0.69 & 3.15 & 7.92 & 37.41 & 37.41 \\
\hline NP23 & ND & 23.20 & $<0.43$ & $<0.73$ & $<0.63$ & ND & ND & 23.32 & 23.32 \\
\hline NP24 & $<0.69$ & ND & 46.55 & 23.24 & 29.46 & 14.28 & 1.22 & 91.31 & 114.55 \\
\hline NP25 & 5.25 & 20.39 & 12.43 & 6.43 & 12.62 & 4.44 & 0.72 & 55.82 & 62.25 \\
\hline
\end{tabular}

"<" values indicate concentrations below the quantification method limit; ${ }^{b} N D$ - not detected

The PCBs congeners profile is graphically presented in Figure 1.

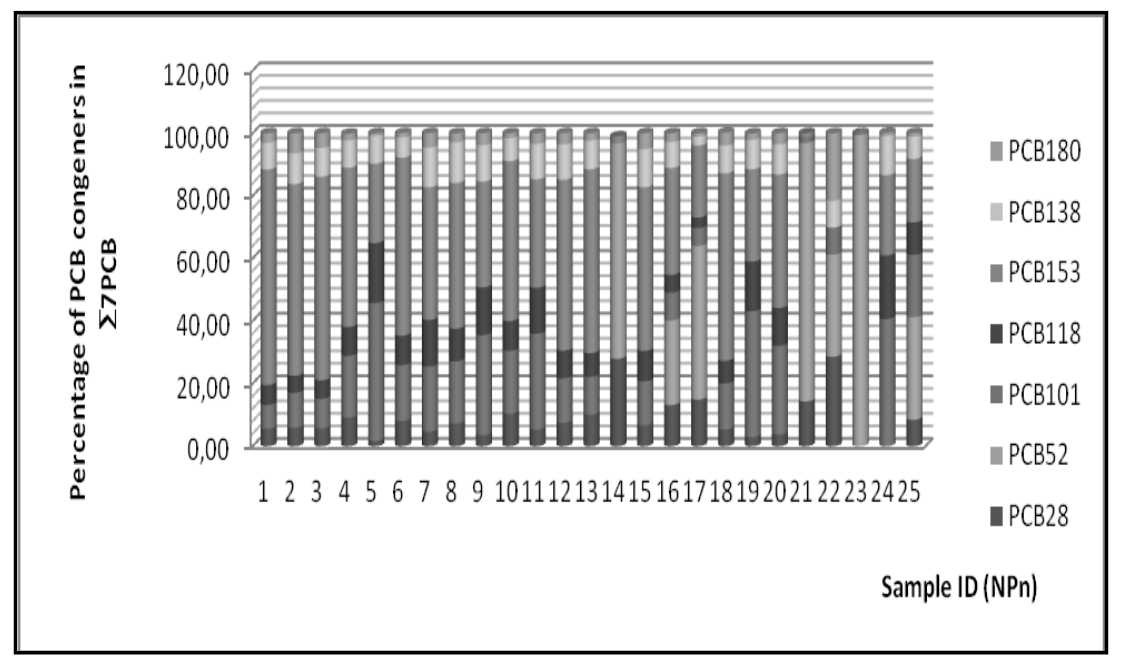

Figure 1. Distribution of PCBs in date mussels samples

The average contents of individual congeners PCB28, PCB58, PCB101, PCB118, PCB138, PCB153 and PCB180 in samples of date mussels analyzed in our study were 2.63, 4.14, 9.98, 4.95, $3.87,14.6$ and $1.32 \mu \mathrm{g} \mathrm{kg}^{-1}$ w.w., respecttively. The dominant congeners both in our samples and samples of shellfish of other researchers (Khaled et al., 2004; Kožul et al., 2010; Scarpato et al., 2010; Nuro and Marku, 2012) were PCB101, PCB118, PCB138 and PCB153. This congeners profile corresponds to the fact that polychlorinated biphenyls with a higher content of chlorine are accumulated in marine organisms in higher percentages in relation 
to lower-chlorinated PCBs (Catsiki et al., 2003).

Specifically, the degradation of PCBs in the environment depends on the degree of molecular-based chlorination of biphenyl, and generally speaking, higher chlorinated polychlorinated biphenyls are more persistent in environmental conditions. Furthermore, the microorganisms have ability of rapid degradation of mono-, di- and trichlorobiphenyls, and slow degradation of tetrachlorobiphenyls, while higher chlorinated biphenyls are resistant to biodegradation by microorganisms (Beyer and Bizuiuk, 2009).

On the other hand, for PCB 180 (heptachlorobiphenyl) our study proved that in the date mussel it was present the lowest concentration of all analyzed congeners (from <ND to $7.92 \mu \mathrm{g} \mathrm{kg}{ }^{-1} w . w$.), and similar results were obtained by some other authors (Catsiki et al., 2003). This result was expected, bearing in mind the fact that the degree of bioaccumulation depends on the number of chlorine atoms and hydrophilicity expressed as an octanol/water partition coefficient $\left(\mathrm{K}_{\mathrm{ow}}\right)$. Namely, congeners with high $\mathrm{K}_{\mathrm{ow}}$ values are less bioavailable for shellfish, because of their greater affinity to bind for the sediment. Thus, by the congeners 180 lower concentration in mussels could be explained with its high-affinity to bind to the sediment (Beyer and Bizuiuk, 2009).

The presence of low-chlorinated PCBs in shellfish such as PCB28 and PCB52 may indicate recent exposure. In the analyzed samples, in our study, both mentioned congeners have been detected, so, based on this data one could suspect a recent exposure of analyzed population of date mussel by these contaminants. However, since it is about the congeners of low relative molecular weight which are characterized by a strong degree of transfer by air, it is difficult to say that this finding was caused by the recent exposure of organisms from a local source of contamination (Beyer and Bizuiuk, 2009).

The European Union provides a limit for the content of the sum of six indicatory PCBs (PCB28, PCB52, PCB101, PCB138, $\mathrm{PCB} 152$, and $\mathrm{PCB} 180$ ) in mussel tissues which is $75 \mathrm{ng} \mathrm{g}^{-1}$ of a wet weight (Commission regulation (EU) No 1259/2011). The content of six PCBs greater than 75 $\mathrm{ng} \mathrm{\textrm {g } ^ { - 1 }} \mathrm{w}$. w. was present in two out of 25 analyzed samples. According to these results, the date mussel from the Neum bay could be assessed as a food product that meet the criteria of the European Union Regulation regulating, among other matters, the content of the analyzed substances present in food placed on the EU market.

\section{CONCLUSION}

The determined content of OCPs and PCBs in the samples of $L$. lithophaga collected from the Sarajevo fish market was within the range acceptable for the use in human nutrition according to the current regulations in Bosnia and Herzegovina and the European Union. By comparing with the EPA's risk tables for the chronic exposure, the concentration of OCPs was in the range acceptable for use in human nutrition. Furthermore, since it is about the foodstuffs for which, due to the law ban on fishing and market price, it could be generally assumed to have a low frequency of consumption, it probably does not pose a significant risk to public health. Certainly, there is a need for more precise research on consumption frequency of shellfish, especially among the local population, in order to evaluate the risk and if necessary, establish the guidelines to protect public health.

\section{REFERENCES}

1. Beyer, A., Bizuiuk, M. (2009). Environmental fate and global distribution of polychlorinated biphenyls. Reviews of Environmental Contamination and Toxicology, 201, 137-158.

2. Bratoš, A., Glamuzina, B., Benović, A. (2004). Croatian shellfisheries aquaculture-advantages and disadvantages. Naše more, 51, 59-69.

3. Catsiki, V.A., Hatzianestis, I., Rigas, F. (2003). Distribution of metals and organic contaminants in mussels from Thermaikos gulf. Global NEST Journal, 3, 119126.

4. Commission regulation (EU) No 1259 (2011). Official Journal of the European Union, L 320, pp. 18-63, pp.18-23.

5. Devescovi, M., Iveša, Lj. (2008). Colonization patterns of the date mussel Lithophaga lithophaga (L., 1758) on limestone breakwater boulders of a marina. Periodicum Biologorum, 110, 334-345.

6. EPA (2000). Guidance for assessing chemical contaminant data for use in fish advisories. In Risk assessment and fish consumption limits. $3^{\text {rd }}$ Edition. Office of Water, Washington, DC. 
7. Galinou-Mitsoudi, S., Sinis, A.I. (1995). Age and growth of Lithophaga lithophaga (Linnaeus, 1758) (Bivalvia: Mytilidae), based on annual growth lines in the shell. Journal of Molluscan Studies, 61, 435-453.

8. Guidetti, P., Boero, F. (2004). Desertification of Mediterranean rocky reefs caused by date-mussel, Lithophaga lithophaga (Mollusca: Bivalvia), fishery: effects on adult and juvenile abundance of a temperate fish. Marine Pollution Bulletin, 48, 978-982.

9. Herceg Romanić, S. (2002). Organochlorine compounds in needles of coniferous trees. Arhiv za higijenu rada i toksikologiju, 53, 21-30.

10. Jones, K.C., Voogt P. (1999). Persistent organic pollutants (POPs): state of the science. Environmental Pollution, 100, 209-222.

11. Khaled, A., El Nemr, A., Said, T.O., El-Sikaily, A., Abd-Alla, A.M. (2004). Polychlorinated biphenyls and chlorinated pesticides in mussels from the Egyptian Red Sea coast. Chemosphere, 54, 1407-1412.

12. Kožul, D., Romanić-Herceg, S., Gašpić-Kljaković, Z., Važa, V. (2011). Distribution of poly-chlorinated biphenyls and organochlorine pesticides in wild mussels from two different sites in central Croatian Adriatic coast. Environmental Monitoring and Assessment, 179 (1-4), 325-333.

13. Miller, J.N., Miller, J.C. (2000). Statistics and Chemometrics for Analytical Chemistry, Doset Press, Dorchester.
14. Di Muccio, A., Stefanelli, P., Funari, E., Barbini, D.A., Generali, T., Pelosi, P., Girolimetti, S., Amendola, G., Vanni, F., Di Muccio, S. (2002). Organochlorine pesticides and polychlorinated biphenyls in 12 edible marine organisms from the Adriatic Sea, Italy, Spring 1997. Food Additives and Contaminants, 19, 11481161.

15. Nuro, A., Marku, E. (2012). An overview of organochlorinated pesticide residues in Albania. Case study: Porto Romano, Adriatic Sea. In The impact of pesticides. Ed. M. Jokanović, Academy Publish.org, USA, pp. 225-239.

16. Pravilnik o količinama pesticida i drugih otrovnih tvari, hormona, antibiotika i mikotoksina u hrani (1983). Službeni list SFRJ, 59/83.

17. Scarpato, A., Romanellia, G., Galganib, F., Andralb, B., Amicia, M., Giordanoa, P., Calvod, M., Caixachd, J., Campilloc, J.A., Benedicoc, J., Centof A., BenBrahimg, S., Elbourh, M., Deuderoe, S., Boulahdidi, M., Giovanardia, F. (2010). Western Mediterranean costal waters - Monitoring PCBs and pesticides accumulation in Mytilus galloprovincialis by active mussel watching: the Mytilos project. Journal of Environmental Monitoring, 12, 924-935.

18. U.S. Food and Drug Administration (FDA) (2002). Inspections, Compliance, Enforcement, and Criminal Investigations, assessed on $14^{\text {th }}$ March 2005 from (http://www.fda.gov/iceci/compliancemanuals/complia ncepolicyguidancemanual/ucm123236.htm).

\title{
САДРЖАЈ ПОЛИХЛОРОВАНИХ БИФЕНИЛА И ОРГАНОХЛОРНИХ ПЕСТИЦИДА У ТКИВУ ПРСТАЦА (Lithophaga lithophaga, L., 1758) ИЗ РИБАРНИЦА У САРАЈЕВУ
}

\author{
Елма Е. Омерагић*, Александра А. Марјановић, Јасмина Ј. Ђеђибеговић, Амила А. Добрача, \\ Мирослав М. Шобер
}
Универзитет у Сарајеву, Фармацеутски фракултет, 71000 Сарајево, Змаја од Босне 8, Босна и Херцеговина

Сажетак: Постојани органски полутанти (ПОПс) су хемијске супстанце које су постале проблем глобалних размера због способности дугодометног транспорта, постојаности у околини, биоакумулације, токсичности и последично ризика од штетних ефеката на здравље људи и на животну средину.

У овом раду је анализиран садржај седам одабраних конгенера полихлорованих бифенила (PCBs, IUPAC Nos. 28, 58, 101, 118, 138, 153 і 180), те шест органохлорних пестицида и то, алдрина, диелдрина, ендрина, цис-хлордана, транс-хлордана и окси-хлордана у прстацима (Lithophaga lithophaga L., 1758) сакупљеним у рибарницама на подручју Сарајева (Босна и Херцеговина). Ова врста шкољкаша, карактеристична по свом спором расту, распрострањена је по целом Медитерану. У Босни и Херцеговини (БиХ) још увек није законом заштићена, те се на тржишту БиХ у слободној продаји могу наћи прстаци изловљени у подручју Неумског залива (Јадранско море).

У раду су примењене методе гасне хроматографије и екстракције развијене у лабораторијима Норвешког института за истраживање вода (НИВА, Осло). Узорци шкољки $(\mathrm{n}=61)$ су били дужине 4,5-8,4 cm. Садржај укупних органохлорних пестицида је био низак (у распону од недетектабилних вредности до $0,419 \mu \mathrm{kg}^{-1}$ с.м.), док се садржај $\Sigma 7 \mathrm{PCBs}$ кретао у распону од 20,26 до $135,37 \mathrm{~g} \mathrm{~kg}^{-1}$ с.м. Доминантни конгенери полихлорованих бифенила у свим анализираним узорцима су били 101, 118, 153 и 180.

Кључне речи: шкољке, постојани органски полутанти, полихлоровани бифенили, органохлорни пестициди, биомаркер изложености

Received: 13 October 2015 